\title{
THE PECULIARITIES OF DEVELOPMENT OF INTELLECTUALLY DISABLED SCHOOLCHILDREN'S SOCIAL ADAPTATION UNDER THE INFLUENCE OF PSYCHOLOGICAL-PEDAGOGICAL SUPPORT
}

\section{Yakovleva S. D.}

\section{INTRODUCTION}

Today, our country is looking for ways to build a new model of social relations, for new forms and methods of younger generation education. These searches, of course, influence also life of children with disabilities - the most socially vulnerable part of our society. The task is complicated by the fact that such searches for new, modern ways are carried out against the background of outdated stereotypes.

The social sphere sees childhood protection as one of the main strategic directions for further stabilization and development of our society, preservation and improvement of the nation's gene pool in order to secure the future of our country.

A complex, branched and differentiated system of educational institutions, rehabilitation and medical-pedagogical centres, educational-upbringing establishments, special institutions provides comprehensive assistance and support to children with disabilities. The socio-psychological aspect of such children's social rehabilitation involves correction of their psychological states, as well as support of their social-psychological adaptation, which in turn can lead to changes in their life situation.

This problem is even more important because of the fact that children with intellectual disabilities have limited adaptive capacity, which causes their social disadaptation and complicates the process of their integration into society. Many scientific studies in physiology, psychology, sociology, pedagogy are devoted to the issue of young people's adaptation to changing life requirements (at school, and later at work, etc.), especially at the present state of socio-economic development. These works discuss the theoretical and practical aspects 
of the issue, the nature of adaptation, its types, mechanisms, structural components and so on.

However, despite the performed scientific studies, the issues of social and psychological adaptation at different stages of ontogenetic development (the basis of which is the ability to communicate), the psychological means promoting such adaptation of schoolchildren (formation of their communication skills, etc.) has not been sufficiently investigated yet.

This issue has not been studied also in relation to schoolchildren at lower forms of special need school and to the difficulties of their social and psychological adaptation. The problem of adaptability criteria, conditions and psychological-pedagogical mechanisms to improve this process at different ages and under different social conditions has not been resolved yet.

The special psychology should resolve not only general issues of correctional education, but also a whole set of problems regarding social and psychological adaptation and socialization of intellectually disabled children.

This research goal is to study the features of social adaptation of intellectually disabled schoolchildren. To achieve this goal, the following tasks were set:

1. to determine the peculiarities of social behaviour formation at intellectually disabled children attending primary school;

2. to substantiate the forms and methods developing social interaction skills of such schoolchildren;

3. to study adaptive processes of children with intellectual disabilities.

\section{Psychological and pedagogical conditions forming social behaviour of schoolchildren with special needs}

Children with intellectual disabilities cannot be integrated into society in the same way as their peers with normal intellectual abilities. Existing disabilities lead to disruption of their ties with society and culture, as sources for their development.

In the current socio-economic situation, social adaptation of children with developmental disabilities (respectively, with special 
educational needs), in particular, their social competence, along with labour skills, is important because it influences decisively on possibility of their further employment.

For successful social adaptation, it is recommended to expand the life and social experience of children with intellectual disabilities. This problem can be solved by means of special education, but there is a problem: it is difficult for such children to apply the knowledge gained with particular objects into everyday life. Therefore, is necessary to pay attention to theoretical knowledge application into everyday life.

At education of children with intellectual disabilities, it is recommended to include them into the process of active practical work $^{1,2}$. Mastering of actions with objects is the most effective under the conditions of emotional, situational-transactional communications with adults ${ }^{3}$.

For successful social and labour adaptation of intellectually disabled children, it is necessary to form at them an adequate perception of their social role and people around them ${ }^{4,5}$. Otherwise, in the future, intellectually disabled children will not be able to choose a profession appropriate to their level of development. It is traditionally considered that the main component and mechanism of socialization is adaptation, under the influence of which a person acquires social traits and becomes a full member of society. However, is impossible to become a social being only under external conditions without internal

1 Баряева, Л.Б. Обучение решению арифметических задач дошкольников с нарушениями умственного развития / Л.Б. Баряева // Дефектология : научнометодический журнал : издается с января 1969 года / ред. В.И. Лубовский. - 1990. № 2. 1990. - С. 66-69.

${ }^{2}$ Белопольская, Н.Л. Оценка когнитивных и эмоциональных компонентов зоны ближайшего развития у детей с задержкой психического развития / Н.Л. Белопольская // Вопросы психологии : издается с января 1955 года / Ред. Е.В. Щедрина. - 1997. - № 1 январь-февраль 1997. - С. 19-25.

3 Жулковска Т. Социализация людей с ограниченными интеллектуальными возможностями / Т. Жулковска ; под ред. и с предисл. А. И. Ковалевой, В.А. Лукова; пер. с польск. - М. : Социум, 2001. - 208 с.

4 Намазбаева Ж.И. Развитие личности учащихся вспомогательной школы // Автореферат докт. психол. наук. М., 1986. 34 с.

5 Чумакова Е.В. Психологическая защита в системе детско-родительского взаимодействия // Дисс. канд. психол. наук. СПб., 1998. 174 с. 
prerequisites. Even sociality of healthy adults is far from complete merge with society; otherwise, there would be no problems of maladaptation, asocial behaviour correction, a person would not experience his/her strangeness in the world of other people. Many researchers emphasize the role of children's group in formation of their active life positions. For this purpose, it is recommended to create a positive microclimate in the group, which allow educators to involve all children into class activities with taking into account their peculiarities and inclinations.

In the course of social development, a person's forms of social interaction with society are changed, the degree of compliance with social requirements and norms grows. The transition from biological to social takes place during phylogenesis.

Some authors combine the concepts of socialization and adaptation, and the latter is understood as a component of the former. They state: "Socialization creates social typing of people, adapts and integrates them into society thanks to assimilation of social experience, values, norms, attitudes peculiar to both society as a whole and to some groups. However, because of an individual's natural autonomy, he/she preserves and develops his/her tendency towards independence, freedom, formation of his/her own position, his/her individuality ... Both tendencies - social typing and personal autonomy - are inherent to socialization and maintain stability, providing, with on the one hand, the renewal of social life, that is, society, and on the other one, implementation of personal potentials, inclinations, abilities ..."6. V.G. Kharcheva in "Fundamentals of Sociology" identifies two forms of socialization: adaptation, or a person's passive adaptation to the environment and its requirements, and integration, or a person's active interactions with the environment, when he/she has the right to choose and exercise influence on the environment. By transforming the environment for him/her and his/her needs, a person is guided by the principles of necessity and

6 Гошовський Я. Ресоціалізація депривованої особистості : [монографія]./ Я. Гошовський. - Дрогобич : Коло, 2008. - 480 с.

7 Харчева В. Г. Основы социологии [Текст] : учебник / В. Г. Харчева. М. : КноРус : Логос, 2000. 302 с. 
expediency. These principles act as determinants of integration between a personality and society ${ }^{8}$.

The natural question arises: what gives rise to adaptation itself as a form, mechanism or component of socialization? In other words, what is the reason for adaptation? In biology, an adaptation purpose determines its course ${ }^{9}$.

The psychological content of adaptation, or its usefulness for a person's socialization, may consist in elimination of such feelings as fear, loneliness, or in shortening of the social learning terms.

Since social adaptation takes place during social interactions of people, the degree of a person's adaptation to a group or society can be determined, on the one hand, by properties of the social environment, and on the other, by the person's own properties and qualities.

Social adaptation is closely linked to social and communicative activities. Social-communicative activities are a set of knowledge, skills and values that determine an individual's appropriate communicative behaviour in the social environment. Socialcommunicative activities of children with intellectual disabilities are understood by us as positive active actions aimed at changes in the surrounding reality and manifested in their ability to harmonize relationships with others, to demonstrate organizational abilities and interests to the problems of children and adults, and to be initiative at different group affairs.

A particularly important pedagogical task for development of social and communicative activities of children with intellectual disabilities is to help them acquire communicative skills and experience. This task cannot be solved by traditional methods, so innovative psychological technologies are more effective here.

The functions of psychologists working with intellectually disabiled children in educational institutions are social adaptation, socialization, and social development of such children; psychological support for children and their families; participation in organisation

${ }^{8}$ Безпалько О. В. Соціальна педагогіка в схемах і таблицях : навч. посіб. / Ольга Володимирівна Безпалько - К. : Центр навч. л-ри, 2003. - 134 с.

${ }^{9}$ Гайденко В. Соціальна адаптація як передумова життєвого успіху / В. Гайденко, I. Предборська // Кроки до компетентності та інтеграції у суспільство : наук.-метод. зб. / ред. кол. Н. Софій (гол.), І. Срмаков (кер. авт. кол. і наук. ред.) та ін. - К. : Контекст, 2000. - С. 111-113. 
and operation of the educational environment that can contribute to children's identity disclosure; study of age and individual characteristics of children having intellectual; disabilities; psychological work with parents; causal diagnosis (revealing the causes of certain social obstacles for personal development); development of psychological and pedagogical recommendations contributing to development of communicative abilities, socialization, social adaptation of such children ${ }^{10}$.

Thus, the content of psychological work in special education institutions is to promote social development of each individual, to identify early the range of his/her problems and to introduce corresponding developmental and corrective psychologicalpedagogical programs.

The psychological-pedagogical programs for development of social-communicative activities of children with intellectual disabilities should consists of certain stages and blocks. The first stage reveals a child's level of social and communicative development. The second stage is diagnostic one, here an individual assessment of the child's social-communicative activities, social problems and his/her neuro-mental state is carried out.

The third stage of psychological-pedagogical work is aimed at development of social and communicative activities of senior preschoolers and junior schoolchildren with intellectual disabilities in educational institutions.

Thus, psychologists' task is to provide psychological support for above activities in an educational institution.

Social behaviour is formed during implementation of corresponding activities. In order to manage an individual's development, it is necessary to organize properly his/her activities in order to influence his/her emotions and behaviour. The efficiency of the traditional means forming social behaviour of children with intellectual disabilities depends on peculiarities of their psyche.

One of the main behavioural traits of intellectually disabled children is their low inhibition ability, which plays a significant role in

10 Липа В.О. Формування адаптивних навичок розумово відсталих дітей як один із елементів модернізації освіти / В.О. Липа // Дидактичні та соціально-психологічні аспекти корекційної роботи в спеціальній школі. Науково-методичний збірник. Вип. 5. - К.: Науковий світ, 2004.- С. 28 - 31. 
their overall nervous-mental activity and influences further behaviour. Children are not able to assimilate behavioural rules and norms without help, they are not able to control their actions and correct mistakes.

Teachers should follow a unified system of requirements during correctional and educational work. It encourages children with intellectual disabilities to follow rules of behaviour in different situations.

The main methodological tool to form social behaviour of children with intellectual disabilities is a clear demonstration of each action and its training. Visual demonstrations and training allow these children to actively participate in learning of rules and norms, to emotionally experience them, to enjoy to be a role model - all these stimulate children to better understand and assimilate the rules and norms of social behaviour.

A lot of information received and encoded at different levels comes from the first signalling system. The ratio between the first and second signalling systems is disturbed because the words' regulating function is underdeveloped. Different by meanings, but close by sounding words are often perceived by children with intellectual disabilities as the same, and correct reactions on them are created only after hard work and long training, and some children do not form these reactions at all. But gradually, speech begins to affect the children's activities and behaviour.

The awareness of social behavioural rules and norms is of great importance for their mastering. Constant, unconditional adherence to norms must become an internal need for children.

The effective education of children with intellectual disabilities often depends not only on the characteristics of their psyche, but also on their ability to perceive the educational influences.

Thus, social development of children with intellectual disabilities depends on their awareness of social behavioural rules and on the depth of their knowledge about the norms of social interactions. This is the meaning of social adaptation.

\section{The dynamics of adaptive process development at children with intellectual disabilities}

Two samples of children were used to solve the put-forward tasks. The first group consisted of 10 schoolchildren of the 3rd form of 
special need secondary school № 1 in Kherson with diagnosed mental retardation, the degree of mild mental deficiency of different genesis, the age of 9-11 years. By gender, they were divided as follows: 4 boys and 6 girls. The second experimental group included 10 children of the 2nd form of general secondary school № 55 with the diagnosis of developmental delay, the age of 7-8 years.

The main research task was to qualify special social adaptation of children with intellectual disabilities. Social adaptation of children with intellectual disabilities is influenced by their intellectual development; this is a basic characteristic to sent a child to a special need school or to a class with individual pedagogical correction (IPC) of a general school or to a regular class of a general school. To solve the put-forward task we used the following techniques:

1) Amthauer IST (the verbal component, since other test components were not available for children with intellectual disabilities at this stage);

2) Spielberger-Hanin Anxiety Inventory. (The score for normative development: up to 30 points - low, 31 - 44 points - moderate; 45 or more - high) ${ }^{11}$.

The research results were processed using quantitative and qualitative methods.

The Amthauer IST data shows that the intelligence level of the experimental group (mentally retarded 10-year old children) do not meet the norms (Table 1).

The table shows that there are significant differences between mentally retarded children and children with developmental delay. General norms:

Level $1-12$ points and the ages less than 6 years

Level $2-12.5$ points at 6.5 years.

Level $3-17-19$ points at 7 years.

Level $4-20-25$ points at 8 years $^{12}$

${ }^{11}$ Психологические тесты для профессионалов/ авт. сост Н.Ф. Гребень. - Минск: Соврем. шк., 2007. - 496с.

12 Тест Р.Амтхауэра, Тест структуры интеллекта (TSI) / Елисеев О.П. Практикум по психологии личности - СПб., 2003. С.342-370. 
Table 1

Indicators of baseline intelligence by Amthauer IST

\begin{tabular}{|c|c|c|c|c|c|}
\hline \multirow{2}{*}{ Group } & \multicolumn{4}{|c|}{ IST sub-tests } & General \\
\cline { 2 - 5 } & $\begin{array}{c}\text { I } \\
\text { Continuation } \\
\text { of sentences }\end{array}$ & $\begin{array}{c}\text { II } \\
\text { Classificatio } \\
\text { ns }\end{array}$ & $\begin{array}{c}\text { III } \\
\text { Analogi } \\
\text { es }\end{array}$ & $\begin{array}{c}\text { IV } \\
\text { Generali } \\
\text { zation }\end{array}$ & $\begin{array}{c}\text { estimati } \\
\text { on }\end{array}$ \\
\hline $\begin{array}{c}\text { Mentally retarded } \\
\text { children n =10 }\end{array}$ & 35 & 51,5 & 39,5 & 32,5 & 157,5 \\
\hline $\begin{array}{c}\text { Children with } \\
\text { developmental } \\
\text { delay n = 10 }\end{array}$ & 40 & 57 & 46 & 39,5 & 182,5 \\
\hline
\end{tabular}

Absence of high scores for the I subtest can be explained by children's insufficient ability to perceive, process and retain information about the world, especially information that is abstract in its nature (for example, avoiding the names of week days, seasons), and can also be explained by the cultural informational environment where children live and is brought up. It should be noted that there are children from incomplete families among the examined ones, such children often do not receive emotional warmth and often left unattended alone. Many children cannot answer the question: "Who lives in the warm lands?" (wolf, bear, deer, camel) or the open statement: "Father is the eldest of his son" (always, often, sometimes, never, rarely). This indicates that mentally retarded children are characterized by impaired abstract thinking, perception. It is difficult for them to imagine anything. It is better if such material is supported by didactic material or practical help of a teacher.

Children with developmental delay also have deviations from normal indicators, which indicate their need in some correction of information perception, storage and reproduction by them.

The "Classification" subtest examines thinking operations, established logical connections between objects, concept formation, the ability to analyze, compare, summarize. This subtest results show that most children failed to answer the question from the first time, they were constantly questioning or even defined the wrong answers. That indicates insufficient formation of concepts, poor ability to analyze, synthesize, compare, classify. The obtained data show that these mental functions are not normal. Life experience and constant corrective work on intelligence development can help achieve higher results. This data applies to both children with mental retardation and developmental delay. 
The low indicators for the third subtest indicate that processes such as generalization, abstract thinking, and the ability to identify essential features are very poorly developed at children with mental retardation. It is difficult for children with such intellectual disabilities to study even at a special need school, because it is difficult for them to formulate questions, to bring their thoughts to a logical end. It is difficult for them to understand task instructions; they are not able to follow in their reasoning the criterion given at question formulating. There is one girl among the studied children who has a severe degree of mental deficiency. Of course, testing with this method was very difficult for her, because all mental functions were developed at a low level, even in comparison with other mentally retarded children. Children with developmental delay also showed poor results, which indicates that their mental processes are underdeveloped and therefore require correction.

The "Generalization" subtest examines formation of the corresponding mental process. The children participated in the research answered less than $50 \%$ questions. They mainly named certain common features of objects (for example, cucumbers and tomatoes grow in the garden; a broom and a shovel clean the yard).

For the obtained data evaluation, we should take into account the peculiarities of speech development, which greatly influences social adaptation. Subtest results indicate insufficient vocabulary of children with intellectual disabilities. Poverty of their speech and limited worldview are the results of these children's underdeveloped speech. Also, the results of subtests filled by children with different society adaptability showed weakness of their arbitrary attention, a high level of exhaustion, and weakness of nervous processes. The comparison of children with mental retardation and developmental delay show clear differences in their speech development, since the vocabulary of children with developmental delay is much wider, these children are better adapted in society, more focused and less restricted than children with mental retardation, but they also need some corrections.

Basing on the obtained indicators and their correlation with age norms, we can say that the intelligence indicators at both groups are low. This indicates low adaptive capacity of mentally retarded children and a slightly higher one of children with developmental delay.

To determine the children's adaptability in society, we decided to determine anxiety with Spielberger-Hanin method. 
The experiment data obtained with Spielberger-Hanin Anxiety Inventory show very low or too high anxiety characteristic for mentally retarded children, which is usual feature of such children.

Table 2

The experiment data obtained with Spielberger-Hanin Anxiety Inventory for the researched groups

\begin{tabular}{|c|c|c|c|}
\hline \multicolumn{2}{|c|}{ Personal Anxiety } & \multicolumn{2}{c|}{ Situational Anxiety } \\
\hline $\begin{array}{c}\text { Mentally retarded } \\
\text { children }\end{array}$ & $\begin{array}{c}\text { Children with } \\
\text { developmental } \\
\text { delay }\end{array}$ & $\begin{array}{c}\text { Mentally retarded } \\
\text { children }\end{array}$ & $\begin{array}{c}\text { Children with } \\
\text { developmental } \\
\text { delay }\end{array}$ \\
\hline 49,4 & 47,3 & 47,4 & 45,7 \\
\hline
\end{tabular}

The children with developmental delay showed personal anxiety at a moderate level, whereas the group of the mentally retarded showed results over the moderate limits and high anxiety.

Situational anxiety for both groups was at a moderate level, within the range of 31-44.

High anxiety needs considerable attention because it precedes a person's anxiety state in the situation of his/her competence assessing. Mentally retarded children are characterized by the state of excitement, which is accompanied by high anxiety. Easily excited children are characterized by the rapid switching of attention from one object to another; they cannot be engaged in one activity for a long time; they are quickly tired, mentally unbalanced. They are inattentive at lessons. They perceive their failures as painful. In communication with peers, they often act as leaders; their role is leading in games. At formation of these children's social adaptation, attention should be paid to psychological peculiarities that greatly affect them; as such children can be easily influenced by bad people or companies.

The children having inhibition as a leading component of their nervous activity are characterized by low anxiety. Such mentally retarded children are passive in all activities, in communication with peers, as a rule, they keep company with peers of similar temperament. Such children are influenced during social development neither positively nor negatively.

After the corrective work on adaptive skill formation, the sociopedagogical orientation of the educational process, formation of interpersonal relationships between schoolchildren, the testing was performed once more with the same methods. 
The performed Amthauer IST showed rise of the results for all subtests, but this improvement was not really high, which indicate the need for longer corrective and educational work. Improvement of the indicators can be expected, since this tendency is detected (table 3 ).

Table 3

Intelligence indicators by Amthauer IST in the process of correctional educational work

\begin{tabular}{|c|c|c|c|c|c|c|c|c|}
\hline \multirow{2}{*}{\begin{tabular}{c}
\multirow{2}{*}{ № } \\
3/II
\end{tabular}} & \multicolumn{8}{|c|}{ Children with developmental delay } \\
\cline { 2 - 8 } & I subtest & \multicolumn{2}{|c|}{ II subtest } & III subtest & \multicolumn{2}{c|}{ IV subtest } \\
\hline$\sum$ & 40 & 48 & 57 & 157 & 46 & 51 & 39,5 & 45 \\
\hline & \multicolumn{8}{|c|}{ Mentally retarded children } \\
\hline$\sum$ & 35 & 40,5 & 51,5 & 57 & 39,5 & 44 & 32,5 & 41,5 \\
\hline
\end{tabular}

The subtests indicators showed a low, but still positive result of corrective work with the mentally retarded children. This indicates the possibility of their social adaptation, but the correction should be continued and be performed constantly and for a long time, as evidenced by the data of Table 3 .

The repeated study with Spielberger-Hanin Anxiously Inventory revealed a slight improvement for emotional sphere of the children from both groups. That is, anxiety decreased slightly, but remained at a moderate level for both groups, and personal anxiety remains at the boundary between moderate and high levels for children with mental retardation and children with developmental delay (Table 4).

Table 4

The experiment data obtained with Spielberger-Hanin Anxiety Inventory in the process of correctional educational work

\begin{tabular}{|c|c|c|c|c|}
\hline \multirow{2}{*}{ Indicators } & \multicolumn{2}{|c|}{$\begin{array}{c}\text { Mentally retarded } \\
\text { children } \\
\mathbf{n = 1 0}\end{array}$} & \multicolumn{2}{c|}{$\begin{array}{c}\text { Children with } \\
\text { developmental delay } \\
\mathbf{n}=\mathbf{1 0}\end{array}$} \\
\cline { 2 - 5 } & Initial data & $\begin{array}{c}\text { After } \\
\text { correction }\end{array}$ & $\begin{array}{c}\text { Initial } \\
\text { data }\end{array}$ & $\begin{array}{c}\text { After } \\
\text { correction }\end{array}$ \\
\hline Personal Anxiety & 49,4 & 45,8 & 47,3 & 42,9 \\
\hline Situational Anxiety & 47,4 & 44 & 45,7 & 41,7 \\
\hline
\end{tabular}

The experimental data obtained with Spielberger-Hanin Anxiety Inventory showed very low or high anxiety of mentally retarded children, which is a characteristic feature for such children. In our 
experiment, children had high levels of both personal and situational anxiety.

High anxiety needs considerable attention because it precedes a person's anxiety state in challenging situations. Mentally retarded children are characterized by the state of excitement, which is accompanied by high anxiety. Socialization of children with intellectual disabilities requires an individual and differentiated approach to each child, which takes into account their psychophysiological development and emotional sphere.

\section{The system of social and pedagogical support for personal socialization}

Development of a system of social and pedagogical support for primary school children's socialization includes several directions of changes: from identification of children's socialization problems existing in the primary school pedagogical process to the analysis of socialization supporting system implementation and requires joint activities of the project agents and their work in cooperation to agree all stages.

Social-pedagogical support of socialization is a process of personal interactions between those who give support and those who need it, and it is aimed at actuation of children's social potential for their successful socialization-individualization on the basis of the humanistic approach, which corresponds to the real status of the modern primary school childhood and allows pedagogically balanced socialization of a personality.

The system of social and pedagogical support contains the following structural elements:

- purpose and objectives;

- priority directions and main forms of adults' work with children;

- ways of adults interactions with children based on the humanistic position of caregivers, social educators, psychologists, parents, and other agents;

- deployment in time and space through step-by-step implementation;

- criteria for effective socialization as a result.

The strategic purpose of the support depends on the purpose of an individual's socialization. Socio-pedagogical support for an individual's socialization creates a spiritual-figural space of education 
as a mechanism for self-realization, so the individual can assimilate socio-cultural values and become a self-sufficient social agent. On this way, education becomes realistic. Otherwise, socialization loses its humanistic meaning and becomes a means of psychological violence, development of conformism, obedience, unification, degradation of human Self ${ }^{13}$.

The real pedagogical approach, implementing the above, emphasizes on personal socializing plan, on the construction by a child in joint activity with adults and peers of such an image of the world that reflects discovery and development by the child of two important life aspects: the world of his/her own Self (as identification and affirmation among others) and the system of ideas and perceptions of the social world - an "image of the social world" (as opportunities to "fit in" to the social environment, to find him/herself in it, to live in the conditions of constant changes). The pedagogy of a primary schoolchild's development as a personality, approved in the Basic Component of primary school education, should be child-centred and help children master the science and art of life, should acts as the basis for an individual's humanistic position formation, for which positive self-acceptance and positive attitude to others are necessary. The socialization goal is a multidimensional construct that can be projected into four "planes" of children's life according to the Basic Component of primary school education. Each plane is only a part, a "slice" of this global goal, and the content of this part is determined by the content of the corresponding sphere in social reality. The analysis of the socialization goals for schoolchildren through the prism of their social and pedagogical support allows us to group the socialization objectives into specific target areas: 1) promotion of children's adaptation to life conditions, introduction of children into the world of human relations, formation of children's openness to the world; 2) promotion of selfawareness dynamics and development, which allows children to change their self-images and attitudes to themselves at the life path, formation of their willingness to perceive social information, development of the skills of social behaviour; 3 ) formation of a child's subjective life position, assistance in self-realization. First and

13 Рогальська І.П. Соціалізація особистості у дошкільному дитинстві: сутність, специфіка, супровід: Монографія / І.П. Рогальська. - К.: Міленіум, 2009. - 400 с. 
foremost, it means education of conscious attitudes to themselves as a free Self and to own duties, determined through relationships with others; children should cultivate the desire to know people and to do good deeds. We consider these objectives as a basis for determining the priority areas and content of adult work with children and for selection of proper forms, methods and means of children's socialization.

The social-pedagogical support should have procedural character, be applied for a long time, be in touch with real daily life of families and primary school, provide personal interactions between the participants.

The main guiding element of social and pedagogical support for children's socialization is teachers' supportive work, aimed at the development of socially and individually significant indicators of children's social formation. The basis of supportive work is a supporting action. Socio-pedagogical support is built on a humanistic basis, which means orientation on a child's personality, helping him/her to become an agent of socialization and own creativity and creation of a favourable psychological climate of security and comfort in a group. It has a preventive and developmental character ${ }^{14}$.

Positive changes in children's socialization and an increased number of children with deep and harmonious socialization as a result can become an indicator of the proposed support effectiveness.

Thus, the introduction into the learning process of educational institutions of systemic social and pedagogical support for children socialization with appropriate methodological approaches and developed programs leads to positive pedagogical achievements at work with children having developmental disabilities.

\section{CONCLUSIONS}

1. The personality of a child with developmental disorders is developed in accordance with the general patterns of children development, and deficiencies, states or illness determine secondary symptoms (according to L. Vygotsky) that arise indirectly because of abnormal social states. Disease, which causes first of all disturbances

14 Рогальська І.П. Соціалізація особистості у дошкільному дитинстві: сутність, специфіка, супровід: Монографія / І.П. Рогальська. - К.: Міленіум, 2009. - 400 с. 
in human biology, creates obstacles for social and psychological development.

2. Intellectual disabilities impede an individual's possibilities to participate in the life of society and make more difficult his/her education and training. And the sooner begins education of such children, the more chances they have for normal social adaptation.

3. The leading component of social work with younger schoolchildren with intellectual disabilities is formation of their individuality and their socialization by taking into account potentials and needs of each child. Construction of children's relationships with their micro- and macroenvironment, development of their preserved psycho-physical abilities can be carried out by expanding their communications, organization of their leisure, games and creative activities, by assistance in their self-care and movement, provision of necessary medicines and food, rehabilitation organization.

4. The key element of social adaptation is experience in social relations and use of the methods stimulating activity and behaviour, priority should be given to promotion of conscious actions, roleplaying games, trainings.

5. For successful social adaptation, we recommend to expand intellectually disabled children's everyday and social experience by means of special education with practical application of theoretical knowledge needed by the children in everyday life.

6. Communication, interpersonal relationships, and the psychological climate at a class, which determine social adaptation, are the main components of the social and psychological support for special need schoolchildren adaptation. Social adaptation is influenced by all social-psychological indicators (communication, interpersonal relationships and the psychological climate) that are determined by activities of schoolchildren, educators and teachers assistants.

The result of the performed experimental research proves that social development of children with intellectual disabilities is influenced by the peculiarities of their intellectual activities, emotional sphere, namely, anxiety and self-attitude, which are an integral feature of these children character.

\section{SUMMARY}

The article discusses social adaptation of primary school-age children with impaired mental development. The need to study 
socialization of such children is conditioned by the difficulties of their social and psychological adaptation to life situations. The analysed experimental data show influence of children's intellectual development on their social adaptation, as well as influence of their emotional states on the adaptive processes of schoolchildren with impaired mental development. The perfumed educational correctional work was aimed at increasing of children's intelligence level and reducing of their emotional tension, anxiety. Thus, social development of children with intellectual disabilities is influenced by the peculiarities of their intellectual activities and their emotional sphere, namely, anxiety, which is an integral feature of these children character, and their self-attitude.

\section{REFERENCES}

1. Баряева, Л.Б. Обучение решению арифметических задач дошкольников с нарушениями умственного развития / за ред. В.И. Лубовского. Дефектология : научно-методический журнал . 1990. № 2. С. 66-69.

2. Безпалько О. В. Соціальна педагогіка в схемах і таблицях : навч. посіб. К. : Центр навч. л-ри, 2003. 134 с.

3. Белопольская, Н.Л. Оценка когнитивных и эмоциональных компонентов зоны ближайшего развития у детей с задержкой психического развития / за ред. Е.В. Щедрина. Bonpocbl психологии. 1997. № 1. С. 19-25.

4. Гайденко В., Предборська I. Соціальна адаптація як передумова життєвого успіху Кроки до компетентності та інтеграџіï у суспільство : наук.-метод. зб. К. : Контекст, 2000. C. 111-113.

5. Гошовський Я. Ресоціалізація депривованої особистості : [монографія. Дрогобич : Коло, 2008. 480 с.

6. Жулковска Т. Социализация людей с ограниченными интеллектуальными возможностями / под ред.. А. И. Ковалевой, В.А. Лукова; пер. с польск. М. : Социум, 2001. 208 с.

7. Липа В.О. Формування адаптивних навичок розумово відсталих дітей як один із елементів модернізації освіти. Дидактичні та соціально-психологічні аспекти корекційної роботи в спеціальній школі : Науково-методичний збірник. Вип. 5. К.: Науковий світ, 2004. С. 28-31. 
8. Намазбаева Ж.И. Развитие личности учащихся вспомогательной школы : автореф. дис... докт. психол. наук. М., 1986. $34 \mathrm{c}$.

9. Психологические тесты для профессионалов / авт. сост Н.Ф. Гребень. Минск : Соврем. шк., 2007. 496 с.

10.Рогальська І.П. Соціалізація особистості у дошкільному дитинстві: сутність, специфіка, супровід : монографія. К.: Міленіум, 2009. $400 \mathrm{c.}$

11.Тест P. Амтхауэра, Тест структуры интеллекта (TSI) / Елисеев О.П. Практикум по психологии личности. СПб., 2003. C. 342-370.

12.Харчева В. Г. Основы социологии [Текст] : учебник. М. : КноРус : Логос, 2000. 302 с.

13. Чумакова Е.В. Психологическая защита в системе детскородительского взаимодействия : дис... канд. психол. наук. СПб., 1998. $174 \mathrm{c}$.

\section{Information about the author:} Yakovleva S. D.

Doctor of Psychological Sciences, Professor at the Department of Correctional Education, Kherson State University 27, Universitetskaya ave., Kherson, 73000, Ukraine 